\title{
Identification of the contaminating psychrotrophic bacteria in refrigerated bulked raw milk and the assessment of their deteriorating potential
}

\section{Identificação da microbiota psicrotrófica contaminante em leite cru refrigerado granelizado e avaliação do seu potencial deteriorador}

\author{
Patrícia Rodrigues Condé1; Cláudia Lúcia de Oliveira Pinto²; Scarlet Ohana \\ Gandra ${ }^{3}$; Renata Cristina Almeida Bianchini Campos ${ }^{1}$; Roselir Ribeiro da Silva ${ }^{4}$; \\ Jhonatan Faria da Costa5; Maurilio Lopes Martins ${ }^{4 *}$
}

Highlights

Bacteria with greater spoiling potential produced lecithinase.

In autumn there was a predominance of proteolytic bacteria at $4.0^{\circ} \mathrm{C}$.

More than $80 \%$ of the isolates belonged to the Pseudomonas fluorescens species.

\begin{abstract}
This work aimed to characterize, identify, and determine the deteriorating potential of the contaminating psychrotrophic bacteria in refrigerated raw milk. Samples were submitted to serial dilutions and plated in specific culture media to form a bacterial culture collection. The isolates were characterized for their morphology and biochemical characteristics. The deteriorating potential of the isolates was determined according to the proteolytic, lipolytic and lecithinase activities at $4.0^{\circ} \mathrm{C}, 6.5^{\circ} \mathrm{C}$, and $25.0^{\circ} \mathrm{C}$. The results obtained for deterioration potential were assessed by the multivariate statistical method and by the principal components analysis (PCA). A total of 159 isolates were characterized, and of these, 46 strongly proteolytic Gram-negative isolates were selected for identification using the API 20 NE kit. The predominant bacteria were Gram-negative and oxidase and catalase positive, with a predominance of bacteria of the genus Pseudomonas. Using PCA, it was shown that the bacteria with the greatest deterioration potential were lecithinase producers, and that, in the autumn, proteolytic bacteria predominated at $4.0^{\circ} \mathrm{C}$. Of the

1 M.e, Professional Masters in Food Science and Technology, Instituto Federal do Sudeste de Minas Gerais, IF Sudeste MG, Rio Pomba, MG, Brazil. E-mail: patricia.conde@ifsudestemg.edu.br; renata.campos@ifsudestemg.edu.br

2 Dra, Agricultural Microbiology, Empresa de Pesquisa Agropecuária de Minas Gerais, EPAMIG, Viçosa, MG, Brazil. E-mail: claudia.epamig@gmail.com.

${ }^{3}$ Food Science and Technology Student, IF Sudeste MG, Rio Pomba, MG, Brazil. E-mail: scarlet05jbgandra@gmail.com

4 Profs., Food Science and Technology Department, IF Sudeste MG, Rio Pomba, MG, Brazil. E-mail: roselir.silva@ ifsudestemg.edu.br; maurilio.martins@ifsudestemg.edu.br

${ }_{5}$ M.e, Professional Master in Science and Technology of Milk and Dairy Products, Universidade Federal de Juiz de Fora, UFJF, Juiz de Fora, MG, Brazil. E-mail: jhonatan.faria@ifsudestemg.edu.br

* Author for correspondence
\end{abstract}

Received: Aug. 11, 2021 - Approved: Dec. 09, 2021 
46 isolates identified, more than $80 \%$ belonged to the species Pseudomonas fluorescens. Thus, attention should be given to the importance of implementing microbial contamination prevention measures in the bulking process, since, even under refrigeration, psychrotrophic bacteria multiply and produce enzymes that deteriorate lipids and proteins, with consequent quality losses of the milk and its derivatives, yield losses in the production of dairy products, and economic losses.

Key words: Lecithinase. Lipolysis. Proteolysis. Pseudomonas fluorescens. Raw milk. Spoilage microorganisms.

\section{Resumo}

Este trabalho teve como objetivo caracterizar, identificar e determinar o potencial de deterioração de bactérias psicrotróficas contaminantes em leite cru refrigerado. As amostras foram submetidas a diluições seriadas e plaqueadas em meios de cultura específicos para formação de uma coleção de cultura bacteriana. Os isolados foram caracterizados quanto à morfologia e características bioquímicas. $\mathrm{O}$ potencial de deterioração dos isolados foi determinado de acordo com as atividades proteolítica, lipolítica e de lecitinase a $4,0^{\circ} \mathrm{C}, 6,5^{\circ} \mathrm{C}$ e $25,0{ }^{\circ} \mathrm{C}$. Os resultados obtidos para o potencial deteriorador foram avaliados pelo método estatístico multivariado e pela análise de componentes principais (ACP). Um total de 159 isolados foram caracterizados e, entre eles, 46 isolados Gram-negativos fortemente proteolíticos foram selecionados para identificação usando o kit API 20 NE. As bactérias predominantes foram Gramnegativas, oxidase e catalase positivas, com predomínio de bactérias do gênero Pseudomonas. Por meio da $A C P$, foi demonstrado que as bactérias com maior potencial de deterioração eram produtoras de lecitinase e que no outono predominaram as bactérias proteolíticas a $4,0^{\circ} \mathrm{C}$. Dos 46 isolados identificados, mais de $80 \%$ pertenciam à espécie Pseudomonas fluorescens. Assim, deve-se atentar para a importância da implementação de medidas de prevenção da contaminação microbiana no processo de obtenção, uma vez que, mesmo sob refrigeração, bactérias psicrotróficas se multiplicam e produzem enzimas que deterioram proteínas e lipídios, com consequentes perdas de qualidade do leite e seus derivados, perdas de rendimento na produção e perdas econômicas.

Palavras-chave: Leite cru. Microrganismos deterioradores. Pseudomonas fluorescens. Proteólise. Lipólise. Lecitinase.

\section{Introduction}

The psychrotrophic bacteria that contaminate raw milk multiply at refrigeration temperatures, the same ones recommended to store this food on rural properties (Gasparini et al., 2020; Yang et al., 2020). When obtained using good hygiene procedures, these bacteria only represent $10 \%$ of the initial microbiota, but the proportion may increase to more than $90 \%$ in situations where failures occur, or in the absence of good milking practices (Cousin \& Bramley, 1981).

The psychrotrophic microbiome is constituted of bacteria with high deterioration potential, characterized principally by the production of proteases, lipases and lecithinase, which hydrolyze the milk protein and fat. This is therefore an important research area for the development of strategies to improve the quality of raw milk. Although the majority of psychrotrophic 
bacteria do not survive pasteurization, many of their hydrolytic enzymes are heat-resistant, and can thus present residual activity even after ultra-high temperature (UHT) treatment (Glantz et al., 2020; Yang et al., 2020). Thus, adequate management and hygiene practices during the milking, storage and transport of refrigerated raw milk play a critical role in the microbiological quality of the milk (Capodifoglio et al., 2016; Yang et al., 2020).

A great variety of genera are commonly found in raw milk, including Gram-negative: Pseudomonas, Aeromonas, Alcaligenes, Acromobacter, Acinetobacter, Flavobacterium, Chryseobacterium, Serratia, Hafnia, Klebsiella, Enterobacter and Rahnella, and Gram-positive: Bacillus, Clostridium, Corynebacterium, Micrococcus Streptococcus, Staphylococcus, Microbacterium, Lactococcus and Lactobacillus, (Capodifoglio et al., 2016) bacteria. Of these, Pseudomonas and Bacillus are the most commonly found isolates in raw refrigerated milk (Pinto et al., 2017; Meng et al., 2018).

The isolation and identification of psychrotrophic microorganisms in raw milk is also important from the public health point of view, since, according to the characteristics of their pathogenicity, certain actions must be taken aimed at improving the quality and safety of this food. Finally, it is of industrial importance, considering the possible deterioration of the milk and its derivatives, with negative consequences for their quality, product yield and economic aspects (De Longhi et al., 2020). Contamination control has become a large-scale concern throughout the world due to the aims of guaranteeing high productivity and yield and of conquering the consumer with high quality products. However, there is a lack of scientific studies that show the deteriorating potential of the psychrotrophic microbiota of raw milk during the different seasons of the year. Thus, this study aimed to isolate, characterize, and identify the predominant psychrotrophic bacteria in refrigerated bulked raw milk, and determine the deterioration potential of this microbiota in each season of the year.

From October 2016 to July 2017, $200 \mathrm{~mL}$ samples of raw milk that had been refrigerated for approximately 48 hours, were aseptically taken from 15 bulk tanks installed on rural properties in the municipality of Rio Pomba, State of Minas Gerais, Brazil, the leading milk producing state in Brazil (Instituto Brasileiro de Geografia e Estatística [IBGE], 2017). During each season of the year, 15 samples were taken, one from each tank, giving a total of 60 samples.

After taking the samples under refrigerated conditions, they were submitted to successive decimal dilutions and analyzed as follows: Standard Methods Caseinate Agar (SMCA - Himedia, Mumbai, India) to count and isolate proteolytic psychrotrophic bacteria (Marcy \& Payton Pruett, 2001), PCA with the addition of $1 \%$ tributyrin to count and isolate lipolytic psychrotrophic bacteria, incubating at $6.5 \pm 0.5^{\circ} \mathrm{C}$ for 10 days (Haas, 2001), and the base agar for Pseudomonas $(20 \mathrm{~g} / \mathrm{L}$ casein peptone, $10 \mathrm{~g} / \mathrm{L}$ potassium sulfate, 1.4 $\mathrm{g} / \mathrm{L}$ magnesium chloride, $13.6 \mathrm{~g} / \mathrm{L}$ agar, 0.025 g/L Irgasan and 20 mL/L glycerol (Interlab, São Paulo, Brazil), supplemented with the following selective agents: $10 \mathrm{mg} / \mathrm{L}$ cetrimide, $10 \mathrm{mg} / \mathrm{L}$ fucidin and $50 \mathrm{mg} / \mathrm{L}$ cephalosporin $\left(\right.$ Merck $^{\circledR}$, Barueri, São Paulo, Brazil), to count and isolate bacteria of the genus Pseudomonas ssp., incubating at $22.0^{\circ} \mathrm{C}$ for 72 hours (Cousin \& Bramley, 1981). 
After incubation, from two to three colonies were selected from the plates with the highest dilutions that presented casein clarification and/or precipitation halos on SMCA agar and clarification halos due to lipolysis on PCA agar with the addition of $1 \%$ tributyrin. Pseudomonas sp. were isolated on base agar for Pseudomonas as from the most diluted samples (Sperber, Moorman, \& Freier, 2001). These procedures were used to obtain the spoilage bacteria present in larger numbers in the raw milk samples. The selected colonies were streaked on SMCA agar and incubated at $25.0^{\circ} \mathrm{C}$ for 24 to 48 hours to determine the purity, isolation and composition of the collection of deteriorating psychrotrophic bacterial isolates.

The purified bacterial isolates that presented a clarification halo on SMCA agar were inoculated into $5 \mathrm{~mL}$ of Tryptic Soy Broth (TSB - Kasvi, Pinhais, Paraná, Brazil) and subsequently transferred to semisolid Tryptic Soy Agar (TSA - Kasvi, Pinhais, Paraná, Brazil), incubated at $25.0^{\circ} \mathrm{C}$ for 24 to 48 hours, and then maintained at $4.0^{\circ} \mathrm{C}$. In addition, $1 \mathrm{~mL}$ aliquots of the cultures of isolates activated in TSB broth were aseptically transferred to sterile cryotubes containing $0.5 \mathrm{~mL}$ of a sterile $50 \%(\mathrm{v} / \mathrm{v})$ glycerin solution, homogenized in a tube shaker and frozen at $-80.0^{\circ} \mathrm{C}$ in an ultrafreezer (SANYO, MDF-U33V, Japan), resulting in a total of 159 isolates.

The psychrotrophic isolates were thus preactivated in TSB broth, seeded in semisolid TCA agar and then characterized for their catalase and oxidase activities, glucose fermentative metabolism (Sperber et al., 2001), morphology and Gram reaction.

The colonies of the 46 isolates with greater proteolytic potential at $4.0^{\circ} \mathrm{C}$, evaluated as Gram negative and non-glucose fermenters, were purified on SMCA agar, incubating at $32{ }^{\circ} \mathrm{C}$ for 48 hours, and then inoculated into a saline solution $(0.85 \% \mathrm{NaCl})$ and the turbidity standardized to 0.5 on the McFarland scale (bioMériex, France). The inoculums were distributed in the galleries of the API 20NE identification kit (bioMériex, France), incubated at $29.0^{\circ} \mathrm{C}$ and then read after 24 and 48 hours, according to the norms of the kit instruction manual. The isolates were identified using the apiweb ${ }^{\text {TM }}$ identification program (https://apiweb.biomerieux.com/ login).

The culture collection isolates were assessed with respect to their capacities to produce proteases, lipases and lecithinases at different temperatures. The proteolytic activity was evaluated using SMCA agar, whilst PCA agar with the addition of $1 \%$ tributyrin and TSA agar supplemented with $5 \%$ of an egg yolk suspension, were used to determine the presence of lipase and lecithinase activities, respectively (Haas, 2001). The isolates were inoculated onto the surfaces of the respective culture media with the aid of a platinum needle, and subsequently incubated at $4.0^{\circ} \mathrm{C}$, temperature recommended by the Brazilian legislation (Instrução Normativa $n^{\circ}$ 772018 ) and at $6.5^{\circ} \mathrm{C} \pm 0.5^{\circ} \mathrm{C}$ (temperature recommended for counting psychrotrophs (Frank, Christen, \& Bullerman, 1992), but which exceeds the limit established by the Brazilian legislation for the storage of raw milk and, unfortunately, frequently occurs on farms) for 10 days, and at $25.0^{\circ} \mathrm{C}$ (optimal growth temperature for most psychrotrophic contaminants in raw milk) for 72 hours.

After the incubation periods, the respective media were checked for the presence of a clarification and/or casein 
precipitation halo in the case of proteolysis, the presence of clarification for lipolysis and the precipitation of lecithin for lecithinase. The diameters of the halos and of the colonies were measured using a digital pachymeter (Homis, Stainless Hardened, Brazil). To assess the deterioration potential, the isolates were ranked based on the ratios between the diameters of the halos $(\mathrm{mm})$ and of the colonies $(\mathrm{mm})$ on the SMCA agar, PCA agar with added tributyrin and TSA agar with the addition of egg yolk emulsion, obtaining nondimensional values denominated as " $x$ ".

The data regarding the microbial counts of the samples were analyzed by comparing the means between the tanks using a factorial analysis of variance with two factors $4 \times 3$ ( 4 seasons of the year and 3 groups of microorganisms) and Tukey's test $(p<0.05)$. Two descriptive analyses were also carried out: one evaluated the biochemical and morphological staining characteristics of the isolates, and the other assessed the deteriorating potential (ratio between the diameter of the halo and diameter of the colony) of the isolates, in the different ranges of dimensionless values found.

The multivariate statistical method of the principal components analysis (PCA) was used to define which isolates stood out in the production of the enzymes protease, lipase and lecithinase at three incubation temperatures $\left(4.0,6.5,25.0^{\circ} \mathrm{C}\right)(n=9)$, so as to show which isolates had greater deteriorating potential. The value used to define the deteriorating capacity of the isolates was the ratio between the diameter of the halo $(\mathrm{mm})$ and that of the colony $(\mathrm{mm})$. The spacing between the collections (qualitative data) was the seasons of the year ( $n=4$; spring, summer, autumn and winter). The PCA calculations were carried out using the PC-ORD program version 5.15 .

Considering the microbial groups evaluated, it was found there was no interaction ( $p>0.25$ ) between the mean counts of microorganisms in the season (Figure 1). However, lower $(p<0.05)$ counts of proteolytic psychrotrophic bacteria were verified in the spring (Figure 1). On the other hand, higher mean counts (between 5.1 to 5.4 Log CFU/ $\mathrm{mL}$ ) were found for lipolytic microorganisms in the winter and autumn, and for proteolytic microorganisms in the winter $(p<0.05)$. The other mean values of microbial counts were between 4.0 and $5.0 \mathrm{Log} \mathrm{CFU} / \mathrm{mL}$ and did not differ $(p>0.05)$. There are no limits in the Brazilian legislation for the presence of these microbial groups, but counts of spoilage psychrotrophics above 4.0 Log CFU/mL in the milk make it unsuitable for the production of some dairy products such as cheese and UHT milk, due to the presence of deteriorating enzymes in sufficient concentrations to compromise the integrity of the casein micelle and fat globules (Cousin \& Bramley, 1981). 


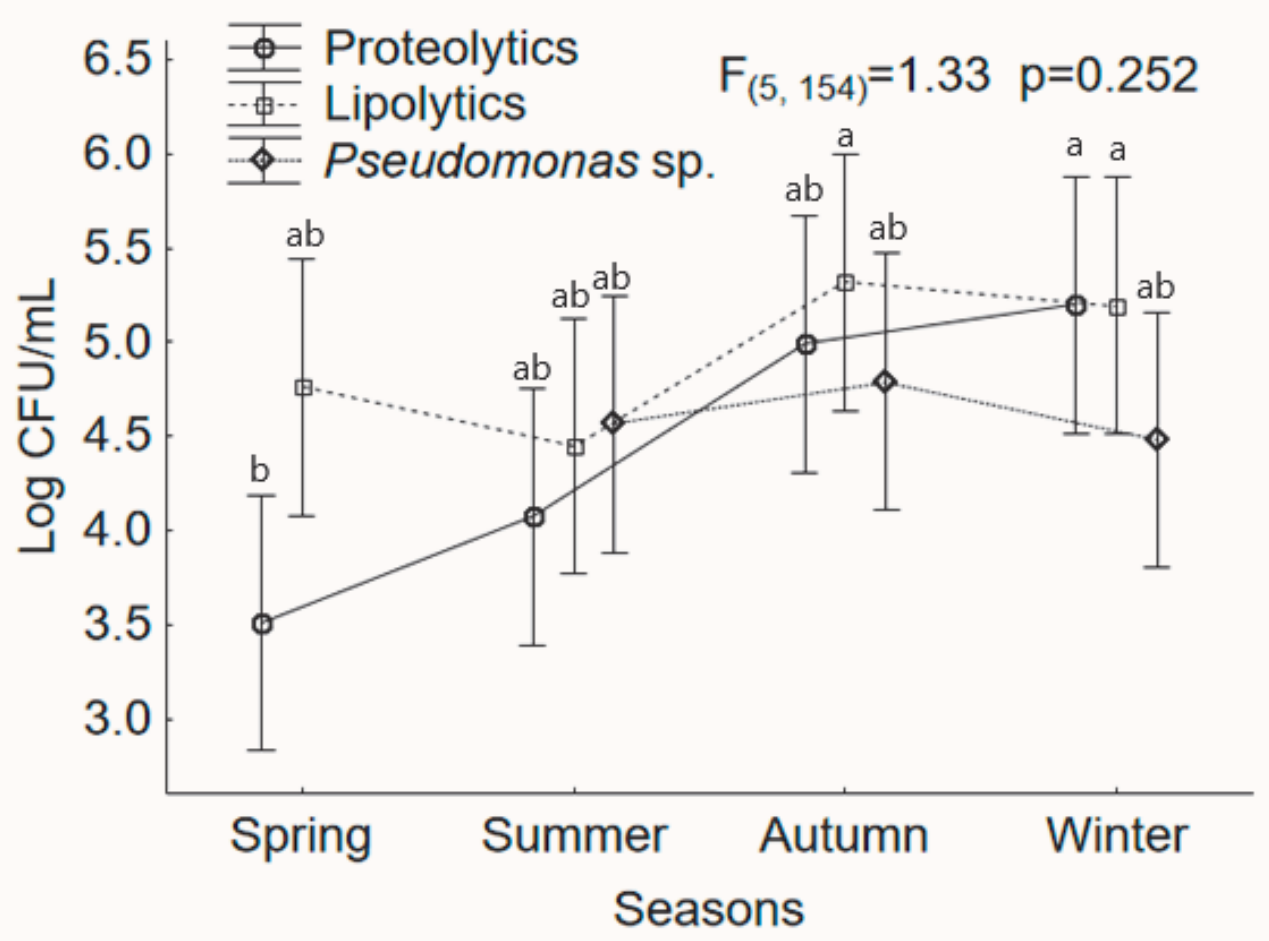

Figure 1. Mean of bacterial counts of cooled raw milk samples. Pseudomonas count was not performed in spring. The confidence interval $(p<0.05)$ is represented by the vertical lines.

Of the 159 bacterial isolates in the culture collection, $61.0 \%, 38.4 \%$ and $96.2 \%$ were Gram-negative, oxidase positive and catalase positive, respectively. Of the Gramnegative isolates, $48.4 \%$ were non-glucose fermentative, a characteristic typical of Pseudomonas. This result is similar to the results observed in another study (Meng et al., 2018).

Of the 46 Gram-negative isolates most proteolytic at $4.0{ }^{\circ} \mathrm{C}$, seven genera were identified, Pseudomonas corresponding to more than $80 \%$ of the isolates, with $P$. fluorescens predominating (38 proteolytic isolates corresponding to $86.61 \%$ of the isolates, of which $76.31 \%$ were also lipolytic, $71.05 \%$ lecithinase producers and $52.63 \%$ both lipolytic and lecithinase producers).
Acinetobacter baumanni was also found (3 proteolytic isolates corresponding to $6.52 \%$ of the isolates, all lipolytic), and Acinetobacter junni/johnsonni (1 proteolytic isolate corresponding to $2.17 \%$ of the isolates, which was also lipolytic), plus Aeromonas hydropyla/caviae (1 proteolytic isolate corresponding to $2.17 \%$ of the isolates), Burkholderia cepacia (1 proteolytic isolate corresponding to $2.17 \%$ of the isolates, which was also lipolytic and a lecithinase producer), Pseudomonas luteola (1 proteolytic isolate corresponding to $2.17 \%$ of the isolates) and Stenotrophomonas maltophilia (1 proteolytic isolate corresponding to $2.17 \%$ of the isolates). These results corroborate the results of another study, where spoilage Gram-negative psychrotrophic bacteria such 
as Acinetobacter, Aeromonas, Burkholderia, Chryseobacteriun

(Flavobacterium),

Chryseomonas, Moraxella and Pseudomonas

(Neubeck et al., 2015) were identified in raw milk stored in refrigerated bulk tanks.

Even at low temperatures, such as $4.0^{\circ} \mathrm{C}$ and $6.5^{\circ} \mathrm{C}$, the psychrotrophic bacterial isolates produced proteases, lipases and lecithinases, demonstrating the high deterioration potential of this microbiota and the importance of implementing good practices to obtain the product hygienically and prevent bacterial contaminations, as well as controlling the storage time and temperature of the refrigerated raw milk, which must be kept at a maximum of $4.0^{\circ} \mathrm{C}$ for the shortest possible time, to restrict the multiplication of spoilage microbiota and the release of extracellular enzymes into the raw milk.

With respect to proteolysis, lipolysis and lecithinase activity, the deteriorating potential was found in $85 \%$ of the isolates at all the temperatures evaluated, with values for $x$ of up to 5 . However, $13.8 \%$ and $7.5 \%$ of the proteolyticisolatespresentedactivitybetween $5>x \geq 10$ at $6.5^{\circ} \mathrm{C}$ and $4.0^{\circ} \mathrm{C}$, respectively. For the lipolytic deteriorating potential, $3.8 \%$ and $5.6 \%$ of the isolates incubated at $6.5^{\circ} \mathrm{C}$ and 4.0 ${ }^{\circ} \mathrm{C}$ presented values for $\mathrm{x}$ between 5 and 10 , respectively, and $1.6 \%$ and $0.6 \%$ presented lipolytic deteriorating potential with values for $x$ between 20 and 35 at $25.0^{\circ} \mathrm{C}$ and 6.5 ${ }^{\circ} \mathrm{C}$, respectively. The greatest deteriorating potential of the isolates due to the action of the enzyme lecithinase was found to be $8.1 \%$ at $25.0^{\circ} \mathrm{C}$ and $6.3 \%$ at $4.0^{\circ} \mathrm{C}$. These results demonstrate that even at $4.0^{\circ} \mathrm{C}$ for up to 48 hours, which is the recommendation of the Brazilian legislation for the storage of raw milk on farms (Instrução Normativa $n^{\circ} 77$
2018), there is intense enzymatic activity of the predominant psychrotrophic microbiota, causing technological problems for the dairy industry.

It was apparent that the greater the ratio between the diameter of the halo and the diameter of the colony in the respective culture media, the greater the deteriorating potential of the isolates, and it was seen that the isolates presented greater proteolytic and lipolytic deteriorating potential at $6.5^{\circ} \mathrm{C}$ and $4.0^{\circ} \mathrm{C}$, as compared to $25^{\circ} \mathrm{C}$. This result reinforces the need to reduce the time refrigerated raw milk remains on the farms, since highly deteriorating species such as Pseudomonas spp. predominate in the psychrotrophic deteriorating bacterial group and have a short generation time at low temperatures as compared to the generation time of the deteriorating mesophilic microbiota.

Using PCA, it was shown that the first two axes explained $53.8 \%$ of the variance in the deteriorating potential data of the isolates at different temperatures during the seasons of the year (Figure 2). This result could be related to the large number of bacterial isolates $(n=159)$, to the deteriorating potential of each isolate at the different temperatures, to the enzymatic activity in the different culture media and to the particularities inherent to the strains and species.

The first axis contributed with $33.6 \%$ of the variance and was associated with the isolates with the greatest deterioration potential related to the production of lecithinase at $25.0^{\circ} \mathrm{C}, 4.0^{\circ} \mathrm{C}$ and $6.5^{\circ} \mathrm{C}$, respectively. In opposition were the sample points containing the isolates with lower values for deterioration potential, located on the right side of the axis (Figure 2). 
The isolates with the greatest values for proteolysis, lipolysis and lecithinase activity in the respective culture media at the various incubation temperatures, were grouped into six groups. The proteolytic isolates at $4.0^{\circ} \mathrm{C}$ belonging to group 2 stood out, which also contributed to the PCA analysis on axis 1 for the formation of the components (Figure 2).
The isolates with the greatest deteriorating potential belonging to groups 1 , $2,3,4,5$ and 6 , were obtained, respectively, in the summer (80.0\%), autumn (87.5\%), summer $(55.6 \%)$, summer $(100 \%)$, autumn $(100.0 \%)$ and winter (80.0\%). Predominance was not found in the spring for any of the groups (Figure 2).

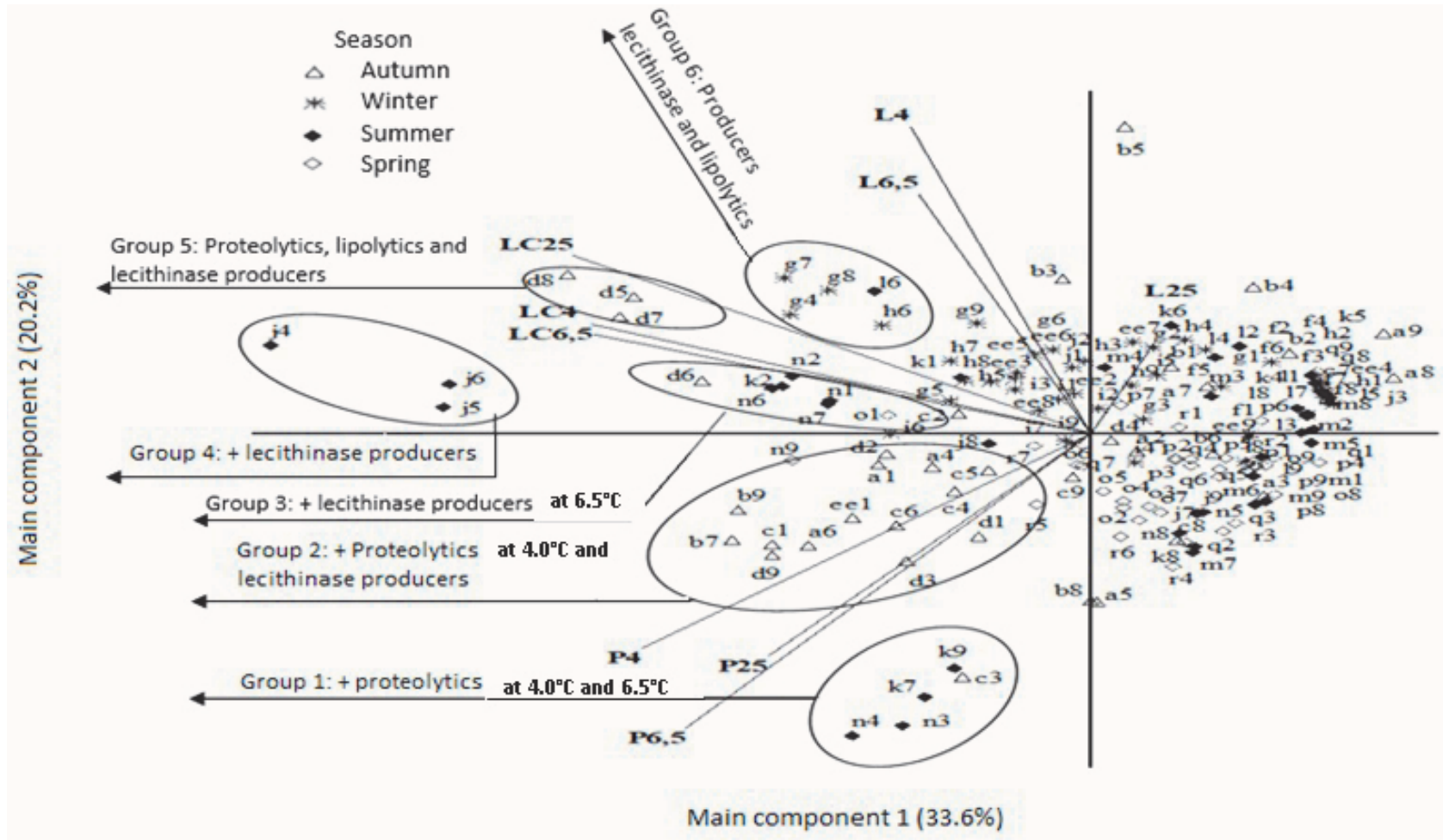

Figure 2. Multivariate analysis $(n=9)$ of the spoilage potential of the isolates $(n=159)$ at $4.0{ }^{\circ} \mathrm{C}$, $6.5^{\circ} \mathrm{C}$ and $25^{\circ} \mathrm{C}$ in the culture media SMCA; PCA plus $1 \%$ tributyrin and TSA plus $5 \%$ egg yolk emulsion, in the different seasons of the year. P4: Proteolytic at $4{ }^{\circ} \mathrm{C}, \mathrm{P} 6.5$ : Proteolytic at $6.5^{\circ} \mathrm{C}$, P25: Proteolytic at $25^{\circ} \mathrm{C}$, L4: Lipolytic at $4.0^{\circ} \mathrm{C}$, L6.5: Lipolytic at $6.5^{\circ} \mathrm{C}$, L25: Lipolytic at 25.0 ${ }^{\circ} \mathrm{C}$, LC4: Lecithinase producer at $4.0^{\circ} \mathrm{C}$, LC6.5: Lecithinase producer at $6.5^{\circ} \mathrm{C}$, LC25: Lecithinase producer at $25.0^{\circ} \mathrm{C}$. Each isolate is represented by a small letter followed by a number. 
The most proteolytic isolates at $4.0^{\circ} \mathrm{C}$ and $6.5^{\circ} \mathrm{C}$ were included in group 1 and were obtained in the summer, except one isolate that was obtained in the autumn (Figure 2). Thus, the dairy industries in the region studied must pay attention to avoid technological problems in the production of cheeses and UHT milk, since the predominance of highly proteolytic isolates in the summer can trigger loss of yield and a bitter taste in cheeses, in addition to sweet coagulation of the UHT milk during the shelf life due to the advancement of proteolysis.

The group 2 isolates stood out because they presented greater proteolytic activity at $4.0^{\circ} \mathrm{C}$ as well as lecithinase activity and were obtained in the autumn, this being the group with the greatest number of isolates (Figure 2). Therefore, the production of dairy products in the autumn in the region studied must be carefully monitored, since in addition to the problems previously mentioned in cheeses and UHT milk, as a result of the activity of heat-resistant proteases produced by the psychrotrophic microbiota, the production of lecithinase (phospholipase) by the isolates leads to hydrolysis of the milk fat globule membrane, which means that the milk fat is unprotected from the action of natural lipases in the raw milk or of microbial origin, in addition to the catalysts of oxidative rancidity. In addition, both lipase and phospholipase act on phospholipids and cause fat separation in the cream and a bitter taste.

Group 3 included lecithinaseproducing isolates with their greatest deterioration potential at $6.5{ }^{\circ} \mathrm{C}$ in all the seasons. The group 4 isolates obtained in the summer were those showing the greatest lecithinase production at all temperatures (Figure 2), and the same isolates also showed proteolytic activity at $4.0{ }^{\circ} \mathrm{C}$. The group 5 isolates obtained in the autumn presented proteolytic, lipolytic and lecithinase activities at all temperatures (Figure 2). It is therefore essential that refrigerated raw milk be kept on farms for the shortest possible time and at temperatures of a maximum of $4.0^{\circ} \mathrm{C}$ at whatever time of the year, to prevent technological problems such as: heat instability of the milk, the development of undesirable flavors and odors in dairy products, a reduction in cheese production yield, and the gelling of UHT milk, amongst others, all arising from the deteriorating activity of psychrotrophic bacteria producing heat-resistant extracellular enzymes.

Finally, the isolates with high lipolytic activity at $4.0{ }^{\circ} \mathrm{C}$ and $6.5{ }^{\circ} \mathrm{C}$ as well as lecithinase activity were obtained in the winter, except for one isolate that was obtained in the summer, and were grouped together in group 6 (Figure 1). Therefore, in the region studied, fatty dairy products such as pasteurized and UHT milk cream and butter, amongst others, are more susceptible to technological defects such as lipolysis and rancidity in the winter.

Of the 46 bacterial isolates identified, 19 belonged to four of the groups, including isolates identified as $P$. fluorescens, which showed the greatest deterioration potential according to the PCA (Figure 2). These isolates were located in group 2 (a1, c1, c4, c5, c6, d1, $\mathrm{d} 2, \mathrm{~d} 3$, ee1, r5 and $\mathrm{r} 7$ ), in group 3 (c2, i6, n2 and $\mathrm{k} 2)$, in group $4(\mathrm{j} 4, \mathrm{j} 5$ and $\mathrm{j} 6)$ and in group 6 (g4).

One paper concerning the composition of the psychrotrophic microbiome in raw milk and its deterioration potential is available in the literature (Xin et al., 2017). However, the microbial communities of raw milk show 
different structures in different geographical areas (Xin et al., 2017). Thus, for each region in each season of the year, it is important to know the predominant microbiota with a high spoilage potential to better target raw milk for the production of specific dairy products and hence obtain high quality dairy products. In addition, knowledge of the deteriorating microbiota at each time of the year can help the dairy industry to better define the shelf life of its products.

Neubeck et al. (2015) evaluated the proteolytic and lipolytic deterioration potential of 966 isolates identified at $6.0^{\circ} \mathrm{C}$ using diffusion assays for enzymatic activity in SMCA agar and PCA with tributyrin. The results were analyzed by observing the production of clarification halos. Twenty-seven per cent of the isolates presented no activity, but $85 \%$ of the isolates of the genus Pseudomomas presented one or both of the activities, and isolates of the genus Acinetobacter showed a very strong tendency to produce lipases, but not proteases. The bacteria of this genus (86\%) showed lipolytic activity. The authors concluded that the deterioration potential of the genus or species could be a combination of the frequency and/or occurrence as related to the counts of individual cells, the intensity of the enzyme activity and the thermal stability of the enzymes secreted.

Thepsychrotrophicmicrobiotashowed different deteriorating potentials in the milk and its derivatives, indicating the importance of developing research concerning the behavior of these microorganisms in order to prevent and control contamination of the milk. However, as found by Gasparini et al. (2020), when evaluating the influence of the psychrotrophic count in milk used for the production of smoked provolone cheese, some technological problems are not always relevant from a sensory point of view, since the tasters did not identify sensory differences between the cheeses produced with milk containing different psychrotrophic counts.

Thus, the raw milk isolates presented high proteolytic, lipolytic and lecithinase deterioration potentials, even when refrigerated. PCA allowed for the separation of the isolates into groups according to their deterioration potential and the seasons of the year, with lecithinase activity standing out. As this enzyme acts by cleaving the phospholipids from the membrane of milk fat globules, they become unprotected from the action of natural lipases in the raw milk or those of microbial origin, which triggers the occurrence of hydrolytic and oxidative rancidity in the dairy derivatives. In addition, the grouping of highly deteriorating psychrotrophic isolates prevalent in raw milk according to the seasons of year can help the dairy industry to better direct the milk to the most appropriate processing, in order to minimize the technological problems caused by this microbiota. Also, monitoring of both the storage time and temperature of raw milk are indispensable measures in the control of contamination by deteriorating psychrotrophic bacteria, in order to obtain high quality raw milk and prevent quality problems and yield losses in dairy products.

\section{Acknowledgments}

The authors are grateful to the Minas Gerais Foundation for the Support of Research - FAPEMIG (CAG - APQ process 03644-14) for its financial support. 


\section{References}

Capodifoglio, E., Vidal, A. M. C., Lima, J. A. S., Bortoletto, F., D'abreu, F. L., Gonçalves, A. C. S.,... Saran, A. Netto. (2016). Lipolytic and proteolytic activity of Pseudomonas spp. Isolated during milking and storage of refrigerated raw milk. Journal of Dairy Science, 99(7), 5214-5223. doi: 10.3168/ jds.2015-10453

Cousin, M. A., \& Bramley, A. J. (1981). The microbiology of raw milk. In R. K. Robinson (Ed.), Dairy microbiology of milk (pp. 119163). London: Applied Science Publishers.

De Longhi, R., Bruzaroski, S. R., Eleodoro, J. I., Poli-Frederico, R. C., Fagnani, R., Ludovico, A., \& Santana, E. H. W. (2020). Presence of aprX gene in Pseudomonas spp. from refrigerated raw milk and their proteolytic ability. Semina: Ciências Agrárias, 41(4), 1421-1426. doi: 10.54 33/1679-0359.2020v41n4p1421

Frank, J. F., Christen, G. L., \& Bullerman, L. B. (1992). Tests for groups of microrganisms. In R. T. Marshall, R. T. (Ed.), Standard methods for the examination of dairy products (pp. 271-286). New York: American Public Health Association, APHA.

Gasparini, G. B. F. B., Amorim, R. F., Bruzaroski, S. R., Fagnani, R., Souza, C. H. B., Damião, B. C. M., \& Santana, E. H. W. (2020). Psychrotrophs in raw milk: effect on texture, proteolysis index, and sensory evaluation of smoked provolone cheese. Journal Science Food Agricultural, 100, 3291-3296. doi: 10.1002/jsfa.10329

Glantz, M., Rosenlöw, M., Lindmark-Månsson, H., Buhelt Johansen, L., Hartmann, J., Höjer, A.,... Paulsson, M. (2020). Impact of protease and lipase activities on quality of Swedish raw milk. International Dairy Journal, 107(104724), 1-11. doi: 10.1016/j.idairyj.2020.104724

Haas, M. J. (2001). Lipolytic microorganisms. In F. P. Downes, \& K. Ito (Eds.), Compendium of methods for the microbiological examination of foods (pp. 175-180). Washington, D.C.: American Public Health Association, APHA.

Instituto Brasileiro de Geografia e Estatística (2017). Censo Agropecuário 2006/2017. Recuperado de https://censos.ibge. gov.br/2012-agencia-de-noticias/ noticias/26457-produtividade-de-leitecresce-62-em-11-anos-producaochega-a-30-bilhoes-de-litros.html.

Instrução Normativa n. ${ }^{0} 77$, de 26 de novembro de 2018. (2018). Diário oficial da união - Imprensa nacional, Brasília, Seção 1, 10. Recuperado de https:// www.in.gov.br/materia/-/asset_publisher/ KujrwOTZC2Mb/content/id/52750141/ do1-2018-11-30-instrucao-normativan-77-de-26-de-novembro-de-201852749887.

Marcy, J. A., \& Payton Pruett, W., Jr. (2001). Proteolytic microorganisms. In F. P. Downes, \& K. Ito (Eds.), Compendium of methods for the microbiological examination of foods (pp.175-180). Washington D.C.: American Public Health Association, APHA.

Meng, L., Liu, H., Dong, L., Zheng, N., Xing, M., Zhang, Y.,... Wang, J. (2018). Identification and proteolytic activity quantification of Pseudomonas spp. isolated from different raw milks at storage temperatures. Journal of Dairy Science, 101(4), 28972905. doi: 10.3168/jds.2017-13617 
Neubeck, M., Baur, C., Krewinkel, M., Stoeckel, M., Kranz, B., Stressler, T.,... Wenning, M. (2015). Biodiversity of refrigerated raw milk microbiota and their enzymatic spoilage potential. International Journal of Food Microbiology, 211, 57-65. doi: 10.1016/j.ijfoodmicro.2015.07.001

Pinto, C. L. O., Souza, L. V., Meloni, V. A. S., Batista, C. S., Silva, R., Martins, E. M. F.,... Martins, M. L. (2017). Microbiological quality of Brazilian UHT milk: identification and spoilage potential of spore-forming bacteria. International Journal of Dairy Technology, 70(1), 1-7. doi: 10.1111/14 71-0307.12339

Sperber, W. A., Moorman, M. A, \& Freier, T. A. (2001). Cultural methods for the enrichment and isolation of microorganisms. In F. P. Downes, \& K. Ito (Eds.), Compendium of methods for the microbiological examination of foods (pp. 37-44). Washington, D.C.: American Public Health Association, APHA.

Xin, L., Meng, Z., Zhang, L., Cui, Y., Han, X., \& Yi, $H$. (2017). The diversity and proteolytic properties of psychrotrophic bacteria in raw cows' milk from North China. International Dairy Journal, 66, 34-41. doi: 10.1016/j.idairyj.2016.10.014

Yang, X., Guo, X., Liu, W., Tian, Y., Gao, P., Ren, Y., \& Man, C. (2020). The complex community structures and seasonal variations of psychrotrophic bacteria in raw milk in Heilongjiang Province, China. Food Science and Technology, 134(110218), 1-12. doi: 10.1016/j.Iwt.2020.110218 